\title{
Public sector research and industrial innovation in Norway:
}

\section{a historical perspective}

Magnus Gulbrandsen and Lars Nerdrum

NIFU STEP, Oslo.

Correspondence: magnus.gulbrandsen@nifustep.no

\begin{abstract}
This paper analyses the historical role of public research organisations for industrial growth and innovation in Norway - and the changes in this role over time. Public research organisations include research institutes and higher education institutions, and we go back in time to the $19^{\text {th }}$ century. Like many other countries, Norway has a large number research institutes involved in innovation, and these organisations have an equally long history as higher education institutions. Public sector research has co-evolved with the national industrial structure, and institutes and universities have played central roles in developing high technology sectors and activities as well as in modernisations of traditional industries.
\end{abstract}

Version of 24.6.2007

TIK Working paper on Innovation Studies No. 20070602

\footnotetext{
*This paper is part of the project "Innovation, Path-dependency and Policy" (IPP) carried out at the Centre for Technology, Innovation Culture (TIK), University of Oslo with the support of the Norwegian Research Council (Contract no. 154877). However, the Centre, University and Research Council are not responsible for the content of the paper, which is the sole responsibility of the author(s).
} 


\section{Introduction}

This paper deals with the historical role of public research organisations or public sector research (PSR) for industrial growth and innovation in Norway - and the changes in this role over time. Public research organisations include research institutes and higher education institutions, and we go back in time to the $19^{\text {th }}$ century. Our main concern is the rationale of PSR and what it has done in terms of industrially relevant activities, but we will also touch on research and innovation policies. Public sector research does not evolve in a vacuum or by policy decisions alone, but it influences and is influenced by the industrial structure and the innovative strategies of firms (Whitley 2003).

Norway is a small and open country which to a large extent has followed international trends in research and innovation policy and institution-building. Templates and inspiration for new institutions and organisations have most often come from abroad, e.g. university and sectorspecific institute models from Germany, Sweden and the U.S. Despite this foreign influence, the Norwegian system has found its own particular form with strong sector-oriented research institutes as a key characteristic - in stark contrast with closest neighbour Sweden which started up such institutes at the same time but which did not develop these into a large separate sector.

Some authors have claimed that the emphasis on university-industry relations is not new but rather a return to an earlier form of knowledge production (Martin \& Etzkowitz 2000; Martin 2003). What the Norwegian case tells us is a more complex story. Tensions between different models of knowledge production have always been present, and complex systemic perspectives entered policies early. Wicken (2007) has argued that the Norwegian innovation system has developed in three different layers with initially little contact between them. The 
first layer, termed “small scale decentralised industries” refers to agriculture and fishery related activities but also key industries like shipbuilding. The second layer, "large scale centralised industries” emerged around 100 years ago with large chemical companies and others dependent upon cheap hydroelectric power. Policy-makers have, especially after WW2, aimed to develop the third layer - "R\&D intensive network based industries" like electronics and biotechnology. We will show how different public research organisations have been established to support each layer, but also that some organisations have become meeting places for all the three layers.

Our paper is organised chronologically. The sections deal with the dominant policies and institutions in each historical period. We start out describing the development of the higher education system and the belief in the transformative power of science around 1900, followed by an account of the first research institutes. In the next sections, we analyse the wartime experience and the renewed belief that science itself was an important source of practical ideas (“science push”), and the increasingly national system of industrial R\&D support including the mission-specific and sector-specific institutes. A table of acronyms and organisations is found in the appendix.

\section{The starting points of the higher education system in Norway}

The two most important public research organisations in Norway before WW2 were the University of Oslo (UiO) and the Norwegian Institute of Technology (NTH) in Trondheim.

\section{The University of Oslo - Norway's Humboldt university}

Compared to other countries, Norway was a higher education latecomer. Although the idea of a university emerged as early as 1629, before UiO was established in 1813 Norwegian students had to go to Copenhagen to become priests or judges (Collett 1999:13). As with 
every other college, university or research institute that followed, there were expectations that the university would help reach important societal and economic goals in Norway. This is perhaps obvious but nevertheless an important point: the government and the public have expected practical benefits from all the public research organisations that have been established. Such a utilitarian component has been a key part of many other countries' higher education and research policies as well, not least the U.S. (cf. Mowery \& Rosenberg 1993).

To help get the University of Oslo started, a large-scale private fundraising took place in the first decade of the $19^{\text {th }}$ century. More than 3,600 individuals contributed, and many university buildings the first 120 years were financed entirely by private donations. Similar processes precede the establishment of other universities and colleges. In Bergen, industry, local banks and individuals worked hard to get a university to the city. Even the University of Tromsø, which is probably the least industry-oriented university in Norway, was first conceptualised by the industrialist and politician Hans Meyer at the beginning of the $20^{\text {th }}$ century. Local savings banks played important lobbying roles in these cities (Sejerstedt 1993:170).

But with the exception of a mining-oriented degree, UiO did little to create educations relevant for industry (Collett 1983:8). Some practical tasks were allocated to the university, e.g. the science part of the national geographical and geological surveys from the 1830s (Schwach 2000:28) which contributed to funding natural science (Collett 1983:32). During its first 120 years the University of Oslo nevertheless became more and more influenced by German "Humboldt” university ideals like “academic freedom” and training as a source of personal development and enlightenment. Close collaboration with industry found little room, and the mining training declined (Hanisch \& Lange 1985:21). In fact, decline happened to the 
whole institution; only two new professorships were established between 1877 and 1890 and at the turn of the century most of the equipment was more than 40 years old (Collett 1983:20).

Examples of institutional collaboration with private firms emerge again in the early $20^{\text {th }}$ century. A professorship of "insurance mathematics" was started in 1913, followed by other professorships and a degree organised in partnership with insurance companies (Collett 1999:120). Even more important was the increasing role of the university in developing the welfare state, e.g. macro economics for political purposes, hygiene and other medical disciplines for improving the population's health, and education for improving schools and social equality. Although the university displayed little interested in industrial collaboration, several well-reputed professors had interests in both basic and applied research (Sejerstedt 1993:149). Some of them successfully combined groundbreaking basic science with remarkable practical contributions. This served as a counterweight to the Humboldtian ideas.

According to Sejerstedt (1993:141), the most practically important academic project was Vilhelm Bjerknes' creation of modern meteorology, a scientific achievement in its own right with large and positive consequences for the productivity and safety of agriculture, fishing and shipping (see Friedman 1989). Also Johan Hjort’s fundamental work in ocean research had huge and broad practical impacts, not least related to mapping of stocks of fish. His charting of sea life also led to the development of a shrimp trawl for use in deep waters (Schwach 2007). Hjort was a key protagonist of the Fishery Board (1900) - the predecessor of the Institute of Marine Research in Bergen - and co-founder of the Whale Research Institute. Positions outside the poorly funded university gave Hjort and others access to much more resources than an academic position alone would have allowed for (Schwach 2000; Collett 1999:141). 
The most well-known example of industrial impact is related to UiO physics professor Kristian Birkeland. He had achieved world fame for his theory that the northern light is due to electromagnetic radiation from the sun at the end of the $19^{\text {th }}$ century, and a few years later he came up with a method for fixating nitrogen from air which could be used for the production of fertilizers (ibid. p. 109; cf. also Andersen \& Yttri 1997). Birkeland teamed up with engineer and entrepreneur Sam Eyde, and supported by foreign capital they set up the company Norsk Hydro (Hydro in short) in 1905. Throughout his career Birkeland worked on both fundamental and more practical problems. His 58 patents and 3 spin-offs signify his importance as an early academic entrepreneur.

Hydro was a major success and soon became the country's largest company, a position held for more than 100 years. It is a prime example of a science-based firm and became a meeting place of science and technology, theorists and practitioners (Andersen \& Yttri 1997:27; Sejerstedt 1993:139-140). Arguably, it showed that the "science push" model worked, at least in some cases. Such arguments had been used for several decades in the public debate, not least by the academic. UiO professor/rector Waldemar Brøgger - the most active participant in the research policy debate for several decades (Collett 1983) - argued that the autonomous advancement of basic science would inevitably lead to industrial applications as well as more general social welfare and "happiness” (Kvaal 1997:66). This was supported by the Hydro case; even practically inclined professors at the technical university NTH embraced the science push model (Kvaal 1997:92). However, the belief in the transformative power of science mainly led to the creation of applied organisations like the technical and agricultural universities (see below) rather than a notable increase in public support for basic research. 
Despite the virtually non-existent basic research funding, it may be claimed that this period constitutes the first "golden age" for Norwegian academic research during which several individuals made long-lasting marks on international science. Brøgger alluded to the practical benefits of science, not least the Hydro case, to secure more long-term public and private funding for fundamental research, but did not succeed. Even science celebrity Birkeland barely received basic funding. Professor Brøgger referred to the National Research Council in the U.S. and the Carlsberg foundation in Denmark and argued about the "duty” of the state and wealthy citizens to support science (Collett 1983, e.g. p. 29-30). In Norway, it may be claimed that the leading professors who collaborated with industry and/or worked to ensure the practical benefits of their research, to some extent so did so because of a lack of public funding of basic research (Friedman 1989 makes this argument about Bjerknes).

\section{The slow birth of the technical university}

Most universities and colleges have been built upon existing organisations: museums, technical schools and/or societies for the advancement of science. The first higher education provider and industrially relevant school was the small Mining School at Kongsberg from 1757 (Collett 1999:24-25). The later decline of the mining education in the mid-19 ${ }^{\text {th }}$ century at $\mathrm{UiO}$ intensified the debate about creating a national institute of technology for industrially relevant research and higher education.

The idea was not new; inspired by the Ecole Polytechnique in Paris all the Nordic countries desired this kind of organisation at the beginning of the $19^{\text {th }}$ century (Hanisch \& Lange 1985:12). The first was established in Stockholm in 1826, the second in Copenhagen in 1829. Norway's did not appear until almost a century later. Behind the first proposition in the 1820s to establish a "Higher technical school” was a group of scientists from the University of Oslo. Their main argument was that R\&D would create new industries and that a national supply of 
engineers would develop the country economically and otherwise (ibid. p. 14-15). But the proponents were alone in their faith in industrialisation in a country whose economy was based on agriculture and fisheries. The Parliament, dominated by representatives of these rural trades, turned down the proposal, arguing that the tiny industry by no means could justify the high costs of creating a technological university.

During the second half of the $19^{\text {th }}$ century, new industries nevertheless grew, not least around the capital Oslo, and the plans for a technological university were reawakened as the demand for technologically skilled candidates was higher than the supply from the lower-level technical schools. But the proponents represented a politically weak and small urban bourgeoisie. Although the Government made several concrete proposals to the Parliament about establishing an Institute of technology, the Parliament voted against it five times before the 1890s. At that point, the demand for skilled technical labour had become so large the issue could no longer be ignored. A geographical struggle emerged between the three cities Bergen, Oslo and Trondheim, all hosting technical schools worthy of upgrading. The industrial interests wanted the new organisation in Oslo, where most of the industry was located, but they had to give up the location battle to be able to get a technical university at all (ibid. p. 32). Parliament voted for establishing the Norwegian Institute of Technology (NTH) in Trondheim in 1900. It was opened by King Haakon in 1910, later than most other European and many South American countries. It is noteworthy that Norway first established public R\&D and training in agriculture and fisheries (the Norwegian University of Agriculture, NLH, 1897, and the Fishery Board, 1900), supporting the small-scale decentralised industry layer of the innovation system, before establishing a technical university supporting the large-scale centralised industry layer (Wicken 2007; Sejerstedt 1993:140). 
The expectations were high with respect to the training and to the R\&D activities at NTH. Initially, only the training activities were successfully implemented; industrially oriented R\&D was difficult to establish (Hanisch \& Lange 1985:69). The professors saw no conflicts between scientific work and practical contributions, but national industry was technologically weak and desired little but quick answers to small technical problems. Some professors had substantial consultancy activity on the side in the 1910s - professor Olav Heggstad employed 30 people in his water power consultancy company. Organic chemistry professor Claus Riiber, with a background from work in breweries in Denmark and Norway, tried to establish a spin-off firm which failed, and he later went into basic research. Attempts at starting a joint lab with chemical company Elkem also failed, and several professors left to work for industry. NTH changed its rules for external activities in 1921, forcing many employees to reduce their consultancy activities, leading most of the remaining professors into basic research with little or no industrial collaboration. This ensuing period of academic isolation was often viewed as problematic by the staff, many of whom were motivated by research at the intersection of basic science and practically oriented technology. But the university staff increased their scientific competence and expertise and came out strengthened to meet new industrial needs two decades later (ibid.).

During the 1930s, NTH tried to approach companies with technological solutions. The university had employed a new category of professors with excellent academic credentials who were eager to help out with industrial development. This strategy of "technology push" received little support in the firms. The best example is the so-called "engine case” (cf. Hanisch \& Lange 1985:121-124). Many Norwegian ships used a primitive early type of electrical engine of which there were more than 120 producers nationally. NTH carried out public experiments to show that diesel engines were superior in performance. No Norwegian 
producers of diesel engines existed, however, and a change of production would inevitably lead to bankruptcies and possibly public support for only a few producers. Professor R. Lutz argued that firms could purchase licenses to make engines, but he was accused of "helping the foreigners" and "not being able to understand user needs and the special national context". Especially in the decentralised industry layer, NTH struggled to find a mediating role between public and private interests, a role the post-war research institutes came to fill 10-20 years later. Of all the engine producers, only Aker started licensed production of diesel engines and this was the only company in the industry that survived. Arguably, the professorial advice to industry failed because the technical university did not have the sufficient trust in industry.

Despite these problems, the University of Oslo in particular, but also NTH and the more specialised colleges, benefited from a tendency in the years before WW2 to view science as a source of rationalisation, systematisation and other improvements of industrial production and society in general (Sejerstedt 1993:160). Chocolate factory owner Johan Throne Holst started sponsoring social science generously, also other disciplines like nutrition physiology (Collett 1999:140). Shipping magnate Wilhelm Wilhelmsen funded a whole department of bacteriology in 1937, and shipping magnate Anders Jahre established a fund for the advancement of science in 1953 which to this day sponsors the most prestigious academic prize of the University of Oslo (ibid.). These private gifts did not come by themselves but were often the result of hard work by particularly entrepreneurial professors (ibid. p. 141).

The industrial expectations were somewhat lower to the establishment of the universities in Bergen, Trondheim and Tromsø, the two latter established in 1968 when the optimism about science had diminished. Some of the engineering colleges, a few of which trace their history back to the technical schools of the $19^{\text {th }}$ century, have been important in serving local/regional 
needs for engineers with bachelor degrees, but these organisations have rarely carried out substantial R\&D. The main exception to this rule is the engineering college in Stavanger, which grew in importance after the town became the "oil capital" of Norway in the 1970s, and it is now an integrated part of the recently established University of Stavanger (2005).

\section{Many plans for starting research institutes}

The first universities in Norway, despite some extremely talented and motivated staff, were relatively weak institutions with little funding and political support. For decades, leading scientists survived on funding for purposes like geological surveys, coastal mappings and housing for poor people. In addition to largely futile attempts at increasing public funding, professors like Brøgger lobbied private capitalists in the beginning of the $20^{\text {th }}$ century for the establishment of private basic research foundations, inspired e.g. by the Carnegie and Rockefeller foundations in the U.S. and the Nobel foundations in Sweden (Collett 1983:4449). For Brøgger and other UiO professors, the ideal was Andrew Carnegies’ claim about the “obligations of wealth” rather than Wilhelm von Siemens' statements about the necessity of publicly supported research institutes oriented at industry (ibid. p. 48). In Norway, neither new basic research organisations nor large private foundations were established, however.

Instead, the belief that technological development should be under the control of users and the demands of production, had a lot of followers in Norway (Sejerstedt 1993:146). Organisations that resembled independent research institutes already existed related to geographical and geological surveys and oceanography/marine sciences. Independent engineer Axel Krefting had suggested the establishment of a public chemical industrial laboratory to help spur a chemical industry as early as 1893, but with little response (Collett 1983:80). Inspired by countries like the U.K., Germany and the U.S., the question of establishing industrially directed public research institutes was formally put on the policy agenda in 1919 (Kvaal 
1997:86; also Collett 1983:91-93). Six institutes tailored at different industries were proposed by the Ministry of Industrial Supply. These organisations should respond to user needs yet be knowledgeable about the academic state-of-the-art in relevant fields. A desire for increased self-sufficiency, in the aftermath of a world war followed by shortage of many raw materials, was a central factor behind these plans.

The technological university NTH, however, wanted a multi-disciplinary “central institute” supporting all national industries. The template had been found in the Mellon Institute in Pittsburgh, U.S. (Kvaal 1997). As expected, the NTH professors wanted this "transfer mechanism” located in Trondheim next to the technical university. This proposal set off yet another geographical battle, and the arguments about whether applied research should be close to industry or close to academic science (that were heard when NTH was established) were repeated (cf. Gullowsen 2000). But all the institute plans fell through due to the economic downturn in the 1920s.

In practice, most early research institutes were formed as industry cooperatives rather than public organisations. The argument that Norwegian industry consists of small and mediumsized companies that need to pool their technological resources, was used frequently (Gullowsen 2000). Many industries considered sharing the costs of a research institute, but only two managed to implement the plans. The paper industry started a research institute in Oslo in 1925 and the canned food industry another one in Stavanger in 1931. Economic problems put other initiatives on hold until after the Second World War, when a set of organisations was established in Oslo for user-controlled R\&D related to breweries (1946), herring oil and flour (1948), wood technology (1949), textiles (1949), leather tanning (1950), potato flour (1950) and brick works (1952). In the same period, a shipbuilding institute and a 
cement and concrete institute were founded in Trondheim. Many of the cooperative industry research institutes got into financial problems in the 1950s and their activities often became integrated into the two large contract organisations SI and SINTEF (Gullowsen 2000).

In addition to the above, the "State Raw Materials Laboratory" was started in one of the University of Oslo’s buildings at Tøyen in Oslo in the early 1920s. It may be argued that this was the first public research institute with an explicit mission to help create new industry. The laboratory was a scientific success but did not live up to the industrial expectations. It moved to Trondheim in 1952 and became part of the Norwegian Geological Survey. Another contract research institute, the Christian Michelsen Institute (CMI), was established in Bergen in 1930 based on a foundation for the advancement of science. Although plans of an upgrading of Bergen Museum to a university had been around for a long time, Norway's second largest city got a cross-disciplinary contract research institute 16 years before it got a university. Again this indicates that the belief in the relevance of science to society first and foremost implied supporting applied research in areas where the country had particular raw materials or other preconditions for generating growth.

\section{Industrial restructuring and research council templates}

In a few cases of the centralised large-scale industry layer, the research linkages were close between universities and industry, particularly Hydro and the other large science-based company Elkem, which started one year before Hydro (e.g. Sogner 2004). Inspired by the Birkeland/Eyde success and supported by government, Hydro and Elkem established very ambitious R\&D projects with the aim to exploit Norwegian natural resources. University professors were frequently involved as consultants or part-time staff in industry, like mineralogy/geochemistry professor Victor Goldschmidt, “one of the greatest scientific talents 
ever”, working for Elkem (Sogner 2004:57-58). Hydro also had many contacts at universities in other countries (Andersen \& Yttri 1997:40-42).

With very few exceptions, these attempts at creating new product lines based on natural resources available nationally, failed completely. Hydro’s efforts related e.g. to coal, titanium, kali, plastic, uranium and artificial fabrics did not lead to new production at all. Sejerstedt (1993) argues that a strategic agreement with German company IG Farben did not allow Hydro to concentrate its efforts sufficiently. Andersen \& Yttri (1997:302-304) similarly indicate that these ambitious R\&D projects did not get enough funding. Whereas Hydro’s foreign competitors used hundreds and occasionally thousands of people in the development of a single technology, Hydro used tens of people on comparable projects. The company spent around one percent of its turnover on $\mathrm{R} \& \mathrm{D}$, far less than e.g. its German competitors (Gullowsen 2000).

This shows another important characteristic of the Norwegian innovation system: even the most advanced companies in the fairly R\&D intensive centralised layer, spent and spend modest amounts on R\&D compared to their foreign competitors. Most industrial companies were small and technologically weak, not least the quite dominant shipbuilding industry (Sejerstedt 1993:155). This may be due to the long delay in creating higher technological education (Hanisch \& Lange 1985:20). The general public was sceptical towards science and theory, and prime minister and Shipping Federation President Aanon Knudsen expressed in 1919 that most tasks in society did not require higher level training at all (ibid. p. 100). The shipbuilders were openly hostile towards "theory" and may have contributed to a technological gap occurring in the transition from steam to oil-based ship engines and thus the later economic disaster in the industry (ibid.). Although the engineers received recognition for 
their work on hydro-electric power stations and the development of big industry, many were nevertheless forced to go abroad to find employment. Few companies hired scientists and engineers. But some of those who did made important innovations in the first decades of the $20^{\text {th }}$ century, e.g. related to paper production and vegetable oil processing (Sejerstedt 1993:147). Public research organisations were not directly involved here. Probably the most important radical innovation in the period between the world wars, the Söderberg electrode, was developed in Elkem's own R\&D labs. This innovation is still unimaginable without the Birkeland-Eyde process creating from scratch a private environment for technology development (Sogner 2004:61), e.g. making it possible for people like NTH professor Peder Farup to find interesting full-time work in Elkem.

There was a significant general increase in industrial activity during the 1930s when the economic crisis resulted in a restructuring of the private sector. Many larger companies went bankrupt, but a vibrant small firm movement created a growth in industrial employment of almost 7 percent annually between 1933 and 1939 (Sejerstedt 1993:181). The mean size of the companies decreased: in 1930, 27 percent of industrial employment was found in firms with less than 50 employees; by 1948 this share had gone up to 42 percent (ibid. p. 181-182). This change is an important precondition for the later establishment of institutes. The restructuring of industry also implied that new firms were formed with modern production methods (Hanisch \& Lange 1985:138). In the second half of the 1930s NTH was thus blessed with a sharp increase in private funding - often for a certain department of laboratory with "no strings attached” and new contacts with industries that previously had little interest in university partnerships. The most important case of the latter is probably the pulp and paper business, where major firm Borregaard provided a professorship in 1936. Even the Confederation of Norwegian Industry, which had sided with the engine producers in their 
critique of NTH the first years of the 1930s, raised a large sum of money for "research at NTH” for the university’s $25^{\text {th }}$ anniversary in 1935.

The first seeds of a "demand pull” R\&D system were sown in this period - i.e. a system where companies gradually increased their capacity to utilise external knowledge and increased their capabilities to define and outsource technical problems. A major element lacking in the Norwegian innovation system pre-WW2 was still the industrial laboratory, with the exception of Hydro, Elkem and a few other large firms. Application-oriented and industryfriendly public researchers found few partners in industry and few domestic users of new technologies. Most continued to do basic research, but often with a sideways glance at what they believed might be relevant for the nation's future. One example is the experiments in the 1930s with feeding of fish larvae by professor Hjort and colleagues which to some extent paved the way for fish farming 40 years later (cf. Schwach 2000; Aslesen 2007).

Funding institutions were also lacking in the pre-WW2 Norwegian system. The State Raw Materials Committee, established in 1917 and led by professor and Elkem consultant Goldschmidt, convinced the Ministry of Industrial Supply to fund some research projects. It was followed by the Central Committee for Scientific Collaboration in Support of Industry in 1918, renamed the Council for Applied Science in 1921. In these organisations were the seeds and templates for the research councils created after the Second World War. One key aspect was that the committees functioned as a meeting place between industrialists, professors and government representatives, or "triple helix"-like organisations to use the term suggested by Etzkowitz \& Leydesdorff (2000), with a potential for mobilising resources from many sectors of society. 
We have seen that Norway does not differ a lot from many other countries in the ideologies and practices of relations between public research and industry. Scientific research was viewed as central to economic and political development just like in other countries. But in Norway this did not translate into long-term and significant basic research funding - neither public funding as in Germany and elsewhere nor large private foundations as in e.g. Sweden and the U.S. Norway was a latecomer in building institutions like universities, research institutes and research councils, and there were few industrial laboratories. Many ambitious professors survived on funding for practical purposes like geological surveys and mapping of fish stocks where Norway was thus one of the first countries to start systematic science-based investigations. Important results came out of this period, like modern meteorology, oceanography and industrial multinational (Norsk) Hydro. Researchers in public organisations in Norway have probably never had as strong incentives/pressures for getting involved in applied/user-oriented work as they had in the first decades of the $20^{\text {th }}$ century. Even the entrepreneurial professors found the lack of basic funding problematic. But the result was still that before WW2 Norway built up scientific competencies in a number of disciplines central to the country’s geography and natural resources. Although some meeting places between public researchers and industry existed, the capability to absorb and utilise the knowledge was largely lacking.

\section{WW2 and the faith in research}

Norway was occupied by German forces from 1940-45. German forces met little resistance in April 1940, which created a strong political impetus for modernising and improving national defence after the war ended. The war created a common mindset where rebuilding the country was at the centre of an ideology with corporative characteristics with emphasis on collaboration between different sectors and groups in society (Hanisch \& Lange 1985:182). Policy-makers had noticed the efficiency of the concerted military R\&D efforts, not least the 
Manhattan project and radar development. The report Science - The Endless Frontier (Bush 1945) was much read in Norway. In 1946, the government-appointed Vogt committee presented a Green Paper on research in technology and natural science. The paper quoted the Bush report claim that a country should be as independent from others as possible when it comes to developing new scientific knowledge, and it embraced a science/technology push rhetoric. The University of Bergen was created in April 1946 and the NTH budget was doubled the same year, indicating that the government for the first time was willing to give out substantial R\&D funding (Kvaal 1997:397).

\section{Military R\&D as an engine for innovation}

As in many other countries at the time (Larédo \& Mustar 2001a) the public R\&D efforts initially emphasised defence and nuclear research. These activities were concentrated in one important research institute established just after WW2: the Defence Research Institute (FFI, 1946). The nuclear activities were later separated from FFI to form the Institute for Nuclear Research (IFA, 1951, later Institute for Energy Research IFE; cf. Njølstad \& Wicken 1997; Njølstad 1999). Norway was the first country in the world apart from the U.S., U.K., France and the Soviet Union to build a nuclear reactor (Njølstad 1999), and despite its small size the country in 1975 became the seventh largest weapons exporter in the world (Wicken 1983).

Central to the creation of new research institutes was a new public-private partnership, the Norwegian Research Council for Technology and Natural Science (NTNF), started in 1946 with Norsk Hydro as a crucial supporter (Andersen \& Yttri 1997). NTNF was given considerable freedom and was not subject to normal bureaucratic control mechanisms and directives. Director Alf Ihlen succeeded in getting the Federation of Norwegian Industry to guarantee that it would contribute with half of the council's funding (Hanisch \& Lange 1985:182). Key employees in the new research institutions were a highly select assembly of 
people, “consisting of well-educated young men closely coupled with illegal intelligence work and often forced to leave the country because of their link with the resistance movement” (Wicken 1994a:16), several of whom had experience from British R\&D during the war. They had the political contacts necessary to pursue their goals, greatly helped by resistance leader Jens Christian Hauge becoming Minister of Defence and centrally positioned in the growing military industry.

FFI was comparable to the (Defence) Advanced Research Projects Agency in the U.S., initiating and leading cutting-edge projects with autonomy for the individuals and groups involved. FFI developed technologies which it looked for private companies to commercialise (Ørstavik 1994). The first success was the development of sonar technology (Njølstad \& Wicken 1997:69-70). The chosen company - SIMRAD - contributed greatly to modernising the domestic fishing fleet and later expanded to other markets (Sogner 1994). From the end of the 1950s, FFI also played a central role in the development of Norwegian computer science. However, the institute often had to struggle to find capable private partners in its technological projects and, after some trial and error, came to concentrate on being a key strategic partner for the two state-owned weapon companies Kongsberg Weapons Factory (KV) and Raufoss Ammunition Factory (RA) (Njølstad \& Wicken 1997:443). Wicken (1983:27) argues that the relatively successful development of these two companies, KV in particular, would not have been possible without the "technological level at FFI and the organisation’s ability to transfer technological knowledge to industrial production”.

Also other public R\&D organisations, such as the (later very successful) cybernetics/automation department at NTH (Kvaal 1994) - which initially faced great difficulties in persuading industry about the potential of automation - used KV as a vehicle 
for early phase commercialization (Wicken 1989). Hence, defence-related R\&D

organisations came to play an important role in the Norwegian post-war innovation system

(Wicken 1992b). This role was much enhanced by the important role played by central actors, such as the before-mentioned former defence minister Hauge, who became chairman of both KV and RA. Hauge, together with the director of KV, Bjarne Hurlen (whom Hauge handpicked) and FFI director Finn Lied (who served as director from 1957 to 1983) constituted central nodes in a network whose influence extended far beyond the defence sector.

\section{Industrial research institutes and knowledge transfer}

Shortly after the war NTNF took up to the earlier idea of creating a large multidisciplinary industry-oriented research institute in Oslo. The Central Institute for Industrial Research (SI) was created in 1950, intended to have close relations to the Faculty of Mathematics and Natural Science at UiO. NTH representatives objected heavily, arguing that technological industry-oriented research should be located in Trondheim close to the technological academic institution. The campaign against SI failed, but a few months later NTH started its own "central institute”, SINTEF. The Ministry reluctantly accepted the creation of SINTEF in order to avoid another devastating localisation battle. In Bergen the Christian Michelsen institute started a technological department around this time.

NTH now entered a new era as an entrepreneurial and proactive university: “The pressure from competing groups released a will to act and ability for renewal that has later been one of the technical university’s main characteristics” (Hanisch \& Lange 1985:213). SINTEF proved to be a highly efficient administrative operation, suitable for handling large numbers of industrial contacts, and came to have a long-lasting, positive influence on research and teaching at NTH (ibid. p. 246). The income from industry made the university less dependent upon ministerial routines and budgeting processes. Positions could be created for talented 
researchers without the Ministry creating new professorships. Companies partnering with SINTEF gained access to a wide range of engineering graduates. SINTEF also built new labs, often co-located with NTH departments. The institute grew quickly to around 2,000 employees in 1993, when it merged with its less entrepreneurial and successful competitor SI, which at that time had around 300 employees.

Norsk Hydro supported the new institutes in various ways but did not use the organisations much for its own R\&D work (Andersen \& Yttri 1997:154). The company was a central advocate behind the establishment of SI and supplied more than 50 percent of the institute's private funding in the 1950s (Gullowsen 2000:30 and 110). Nuclear institute IFA received deuterium for 6 million NOK from Hydro at the end of the 1940s (a formidable sum at the time), and the SINTEF materials section received half a million NOK as a start-up gift (Andersen \& Yttri 1997:155). The main interest of the company was to create a technological cluster nationally which it hoped to benefit from more generally.

The first Norwegian R\&D statistics from 1963 confirms the important role played by the institutes and the modest role played by private industry. Close to one half of total $R \& D$ in that year was carried out by the institute sector. Barely 200 firms were involved in R\&D, and this spending constituted only about 1 percent of these firms' turnover (cf. Skoie 2005:208). In total just above $1,000 \mathrm{R} \& \mathrm{D}$ man-years were carried out by scientific staff and technical support staff in industry; compared to, for example, around 14,000 in 2005.

The industry-oriented NTNF research council was worried about these figures and developed a strategy document in 1964, arguing for increased investments in education and research (see Skoie 2005:208). In industrially relevant fields, the council suggested a division of labour in 
three areas. First, the public should take responsibility for long-term research, R\&D related to “infrastructure” (defence, telecommunication, roads, railways etc.) as well as related to “national strategic areas” like the exploration of natural resources and energy supply. Second, private firms should take responsibility for R\&D close to production and new product development. Finally, a third area should be characterised by “collaboration and sharing of work”. This included the build-up of competence in advanced areas like automation as well as large projects involving many different firms or industrial sectors. Government followed up the recommendations e.g. by establishing an industrial development fund and R\&D contracts related to public procurement, by allowing NTNF to support industrial research directly, as well as giving the industry collective (private) research institutes some basic funding. Most of these new mechanisms were placed outside of NTNF, unlike Finland where TEKES grew to become a key innovation policy actor. Skoie (2005:212) argues that the Norwegian policymakers were opposed to NTNF getting an even stronger position in the research system than it already had. The responsibility for innovation policy in Norway was thus spread out on a number of actors.

It should be emphasised that many countries developed industry- and mission-oriented research institutes in this period. The Fraunhofer institutes in Germany, now employing more than 12,000 people, are quite similar to the SINTEF ones in the mixture of old sector-specific institutes and institutes started by university departments (cf. Meyer-Krahmer 2001). The Dutch TNO institute with close links to technical universities is also quite similar (see van der Meulen \& Rip 2001). The Finnish VTT, although initially a technological service institution, also gradually evolved into a multidisciplinary technological institute of the SINTEF type (Sörlin 2006). In other words, seeing Norway as an odd example with an unusually dominant institute sector is not correct. 


\section{Universities, institutes and industry}

Following WW2, the Norwegian universities received a significant and steadily increasing basic funding for the first time. Technological research was, however, concentrated at NTH and in the institutes. The other universities' incentives and opportunities for industrial collaboration were therefore minimal during the first three decades after WW2 and, as in many other countries (Martin 2003), little interaction with industry occurred.

Nevertheless, individual professors interested in practical application had ample opportunity through mission-oriented institutes (FFI, IFA), institutes related to e.g. geology and marine research and institutes more directly tied to industrial needs such as SINTEF and SI, and such activities initiated and controlled by the researchers were arguably as important for industrial development as more short-term contract work (Moe 1999; Gullowsen 2000).

In fact, many projects in the institutes in the post-war decades were state-of-the-art and required high scientific and technological competencies. Most of the new fundamental results in electronics and reactor technology came from the research institutes, not the universities (Ørstavik 1994). Boundaries were blurred; SINTEF e.g. soon became involved in teaching and the operation of "supercomputers" at NTH (Gullowsen 2000). The research institutes also contributed to bring the actors in the innovation system together to work on state-of the-art technological initiatives with industrial potential, a good example of which may be the Penguin Missile project, probably the largest concentrated R\&D effort ever in Norway. To some extent the ideals of the new institutes were U.S. technological universities like MIT and Stanford (Ørstavik 1994). For instance, senior FFI/IFA researcher Helmer Dahl suggested a set of MIT-inspired reforms at NTH to bring the technical university up to date with the technological and scientific frontiers (Collett \& Lossius 1993). Following these ideals 
institutes like FFI and IFA searched for professional niches where there were opportunities for attaining scientific excellence and even “world leadership” (Njølstad 1999:517). In his way the institutes functioned as a vehicle of change for the university sector, particularly NTH.

We thus see a sharing of work between public research organisations related to the different layers of the innovation system (Wicken 2007). The firms of Layer 1 - the small scale decentralised industries - found public partners particularly in the SINTEF structure, the postwar collective institutes as well as other organisations such as the institute for marine research. For example, shipyards saw a renewed growth period in the post-war period. The industry’s technological edge and competitiveness rested mainly with strong networks between shipowners, yards and supply industries. Two key innovations from the early 1950s were developed in collaboration with SINTEF and the Ship Model Tank at NTH: pitched propellers and passive stabilisation of vessels (Andersen, 1997:469). From the 1970s onwards, involvement in the booming oil industry became very important to the yards, and the SINTEF/NTH cluster was part of most R\&D projects, as the firms preferred to use external sources rather than to build own R\&D units (ibid.). Firms of Layer 2, the large scale centralised industries of e.g. chemicals, metals, pulp and paper, to a larger extent had their own R\&D laboratories and co-operated with NTH, the agricultural college and other universities directly. Finally, the R\&D intensive network industries of Layer 3, receiving much public support related to defence and electronics, had a strong and proactive research base in Norway (Ørstavik 1996), particularly in the defence research institute FFI.

Over time, public research became very heterogeneous; even within the heading "institute sector" we see a multitude of organisations with very different framework conditions. In an evolutionary framework, institutes created new variety but also constituted a selection 
mechanism for innovation. Through their contact with the universities and with the international research frontier, they were able to suggest new opportunities and new solutions to the companies. However, they depended upon client funding and upon public funding with many strings attached (regional, industrial, disciplinary and technological), and they had a strong technology push perspective. This often meant that they transferred a single technological solution to a whole industrial sector or group of firms. What may be particular to the Norwegian industry-oriented institutes was that all of them had relatively close ties to universities. Furthermore, the institutes soon became a meeting place for all layers of the innovation system.

\section{The creation of a national innovation system}

A strong innovation support structure with a broad systemic orientation was created in the 1960s and the 1970s (Wicken 1994b). This included publicly funded research, public risk capital to technology-based industries, tax deductions for R\&D, technology developmentoriented public acquisitions, public agencies with plans for technological development, public R\&D contracts and structural control of high-tech industries. Although these mechanisms were not the result of a single policy, the end result was a system at the national level with many linkages between firms and public research organisations. Research policy and large parts of industrial policy were decentralised and sector-based where each ministry had the initiative and responsibility for R\&D within its field of operation. Most ministries were responsible for one or several research institutes used as a means to attain other goals than scientific development.

From the 1960s, most large industrial companies in Norway established regular collaboration with NTH, other universities and relevant research institutes. Hydro’s fertilizer division formalised its links to the Norwegian Agricultural University (NLH) in 1968 with which it 
had enjoyed informal links for more than 60 years (Andersen \& Yttri 1997). The new Hydro aluminium division had large-scale collaboration with IFA, SI, SINTEF and NTH, and regarded the two latter as world-class within metallurgy (ibid.). The magnesium division, however, was based completely on technology developed in-house. Companies like Elkem used NTH and SINTEF for process innovations (Sogner 2004). Pharmaceutical large firm Nycomed, now a part of General Electric, developed strong ties to the University of Oslo, while Hydro’s oil and gas division entered a long-term relationship with the university and research institutes in Bergen. The divisionalisation of large companies and decentralisation of industrial R\&D had positive effects for the public research system, as the companies became less self-supplied and more dependent upon external sources of knowledge (Gullowsen 2000:110).

In the same period, many smaller high technology companies expanded their linkages to public research organisations. For example, SIMRAD, founded on FFI-developed technology, changed from being part of a smaller technological and partly regional system involving FFI and the Institute of Marine Research. Instead it became part of a national innovation system within maritime electronics with NTH and SINTEF as large and professional actors, which is viewed as a precondition for the company’s transformation into a relatively large

multinational firm (Sogner 1997:100, 173). With increasing national ties between industry and particularly the research institutes, the organisations co-evolved into a strongly integrated system. Below we describe the development in two important sectors: electronics/computers and oil/gas. For more details, see Sogner (2007) and Engen (2007).

\section{Electronics: the modern and top-down planned industry}

Electronics was in the 1960s viewed as a "key industry" to developing a modern society (Collett 1984). The industry received massive public support for R\&D and other activities, 
and NTNF's influential report on electronics from 1964 switched the attention from supporting research institutes to funding a few companies more directly (ibid.), similar to developments in France and other European countries (Larédo \& Mustar 2001b). The electronics industry became a major institute partner, purchasing more than 50 percent of its R\&D in institutes like SINTEF, SI, FFI and CMI (Basberg 1986). However, the national champions failed to become large, mass-producing international corporations. Even weapons producer $\mathrm{KV}$, which was successful for at least two decades, was terminated at the end of the 1980s - leaving behind a regional cluster of small and medium-sized technology companies, many within automotive and maritime materials and electronics for civilian markets.

On the civilian side, the national telephone company gradually became the most central actor in the electronics research system. The phone company was under political pressure and decided to establish a central laboratory in 1967 - Televerkets Forskningsinstitutt (TF) which was located next to FFI just outside of Oslo. TF was established with a radical R\&D strategy: its research should be state-of-the-art and not merely oriented at incremental improvements. The lab took on a national responsibility for "technological upgrading” and industrial development that would ensure that "national independence" was not endangered (Collett \& Lossius 1993:37-39). FFI and particularly SINTEF Elab were partners and driving forces in the development at TF. Elab was established in 1961 to transfer knowledge from the Electrotechnical department at NTH, but the SINTEF division was allowed to initiate own projects and to take on contracts without the direct consent of the university department (Gullowsen 2000:160-217). Elab director Aasmund Gjeitnes, in this position for 23 years, made the lab take on large projects of a "breakthrough" type. His governing principle was that research should be equally oriented at industry, at the public sector and at the NTNF research council. Director Nic. Knudtzon at TF had a similar view, wanting technological R\&D to be 
carried out in a triangular relationship between itself (representing the public sector), the research institutes (backed by the universities) and industry. This resembles a systemic "triple helix” approach (cf. Etzkowitz \& Leydesdorff 2000). It was the beginning of a three-decade close collaboration, assisted behind the scenes by the same individuals that figure in many of the other case examples: FFI director Lied who had served a period as minister of industry and was on the board of the telephone company, former minister of defence and justice Hauge and former minister of industry Kjell Holler who later was director of the telephone company.

Perhaps the greatest technological success of the SINTEF Elab-TF relationship was the GSM mobile telephone system. There had always been a great need to communicate efficiently with the many small fishing vessels close to the coast, with the large merchant fleet worldwide, and now also with the offshore oil platforms. The Nordic telephone companies had in 1981 gained international recognition for developing the NMT mobile phone system, the result of a publicprivate collaboration across national borders. The work towards a new international mobile phone system was coordinated by an international group based in Paris, and many of the largest electronics firms in Europe developed proposals. In Norway, TF and Elab worked intensely to develop a solution that was 100 percent digital, which would greatly increase the system's capacity. After a technical competition, the Norwegian solution was deemed a clear winner. This was a popular result internationally, as there were no industrial interests behind the Norwegian proposal. Other countries' firms could therefore develop, produce and market the equipment. The main benefit for Norway was that the selected system was well suited to the country's particular challenges. But no large-scale industrial production was developed in Norway. Some important reasons were the cross-country ownerships in the telecom industry, intellectual property regimes, problems with the top-down political planning model and lack of complementary assets (see Sogner 2007 for more). 
Public research organisations also played a major role in the development of a national industry within the computer field - "the computer industry to a large extent came out of the [public] research system” (Wicken 1989:19). NTH was central, not least for establishing the companies Computer Techniques and Norcontrol at the end of the 1960s. In addition to NTH, FFI, the astrophysics department at the University of Oslo, the Central Institute for Industrial Research (SI) and Norsk Regnesentral (NR) in Oslo and CMI in Bergen were also part of the computer industry’s development (Wicken 1989; Kvaal 1994). Key company Norsk Data (ND) was founded as a spin-off by three engineers from FFI in 1967 and grew quickly to become a large mini-computer company with major international activities. It went out of business at the end of the decade, unable to adapt to the era of personal computers. The same happened, although for different reasons, to the other major Norwegian computer firm, the defence company KV (Sogner 2007).

Should we then regard the attempts at building an R\&D intensive network industry (Layer 3 in Wicken 2007) through supporting advanced $R \& D$ in research institutes, as a failure? It is clear that such high-tech industries are smaller in Norway than in neighbouring countries Denmark, Sweden and Finland. Still, it is noteworthy that the present-day electronics firms in towns like Kongsberg and Horten now employ more people than the big national champions did before they were terminated. This indicates that benefits from applied research may take a long time to appear, and perhaps that it was beneficial to the industrial development that research and innovation policies were to some extent relieved from the weight of regional development policies. It is also noteworthy that many of the present-day electronics firms are specialised in areas like maritime electronics, process automation and offshore control systems which are oriented at the other two layers (the decentralised small and the centralised 
big industries) in the innovation system in Norway. High technology firms seem to have succeeded if they have been able to tailor their expertise to the needs of the firms in “traditional” industries. Public sector research has probably played a role to bring the layers of the innovation system together, for example when FFI developed sonar systems used by the fishing fleet and NTH/SINTEF developed process automation systems used by large firms.

\section{The oil and gas industry: not starting from scratch}

Public research organisations in different cities played major roles in the development of technologies for the oil and gas industry. Particularly strong linkages developed between Statoil and the institute Rogalandforskning (RF) in Stavanger and between Hydro and the University of Bergen and the Bergen-located research institutes. NTH, SINTEF, the Geological Survey of Norway, SI, IFA/IFE and others contributed with important innovations for the whole industry. In the early phase the technology agreements (1979-1991), stating that drilling rights in the North Sea were only given to companies doing a certain amount of offshore-related R\&D in Norway, were an important impetus, leading to rapidly increasing funds for such research. Approximately half of this went to Norwegian research institutes with SINTEF as the main recipient.

The oil industry did not start from scratch - it is a case where public research organisations in e.g. geology, marine technology, materials and electronics played a "preparedness role”. They were important as a small pool of knowledge which could be expanded when the need arose in the early 1970s. Some moved into new areas; IFE (nuclear research) is a good example. It entered electronics, computing and petroleum technology, and these areas soon became as important as the traditional nuclear research activities. These moves were still based on areas where the nuclear research had resulted in particular expertise, e.g. reservoir modelling, process automation and corrosion problems (Njølstad 1999:398). A conservative estimate is 
that IFE results alone have saved the oil companies of "hundreds of millions" in reduced material and maintenance costs. Njølstad (1999: 522-523) indicates that this would not have been possible without the build-up of scientific competencies in the 1950s and 1960s, and he argues that the decision to spend 5 million NOK in 1947 on Randers' reactor project may have been the best public R\&D investment ever in Norway.

Technology and "goodwill" agreements changed the structure on the demand side of Norwegian R\&D completely. Seven of the nine largest buyers of R\&D from SINTEF in 1987 were oil companies. These seven firms furthermore bought R\&D for 410 millions this year, while all other large customers purchased R\&D for 110 millions (ibid. p. 76). The 1970s are therefore an important turning point for all Norwegian technological research. Research institutes became increasingly dependent upon a few large customers. The institutes thus became vulnerable to changes in the organisation and extent of private R\&D.

The oil and gas industry is important but not all-dominating. Its share of total private R\&D has been decreasing since the mid-1980s and went below 10 percent in the 2000s. One reason could be, however, that much of the knowledge and technology development in the industry is carried out in firms which are classified as something else, e.g. electronics, software and materials. Many important support companies for the oil and gas sector are spin-offs from research institutes like Rogalandsforskning in Stavanger. The industry is seen as a national success first and foremost because it exists - which was not at all an obvious to many people in the late 1960s when oil was fund - and also because of the build-up of a national supply and engineering industry which increasingly competes internationally. 


\section{Tensions towards a new millennium}

For more recent developments regarding university-industry and institute-industry relations, we refer to Gulbrandsen \& Nerdrum (2007) and Nerdrum \& Gulbrandsen (2007). Some changes will be mentioned here, however, and it must again be emphasised that these are not unique to Norway. Increased weight on user control and improved relations between public research and industry, liberalisation/privatisation, as well as an increased weight on "basic research” in recent years, are seen all over Europe (cf. Larédo \& Mustar 2001a).

Substantial changes have happened to public sector research the last 20-30 years. One central development is “massification”, referring to the enormous increase in student numbers. The funding of university research and the number of faculty members is largely dependent upon the number of students, and the volume of university research in Norway has more than doubled since the early 1980s. Two colleges have been upgraded to universities, and more will probably come as close to 100 specialised colleges were merged into 26 larger state colleges in the 1990s - several with clear university ambitions. All of the research institutes referred to in the previous sections, still exist. New regional institutes with a social science profile have been established in the 1980s. Liberalisation and increased weight on user control has increasingly created financial problems for many institutes, however, and the sector has become a somewhat less visible actor in the research system. It should also be mentioned that all five research councils, including university-oriented NAVF and technical-industrial NTNF, were merged into one research council in 1993. This has probably contributed to competition and strains between the institutes and the higher education institutions.

The late 1970s and 1980s saw increased tension between universities and institutes, not least NTH and SINTEF. The latter was increasingly displeased with professorial control of the 
institute's activities; it could not follow a strategy or enter a project which might be seen as a threat by NTH (Gullowsen 2000:68). Director Stenstadvold never challenged the professors fearing they would find other outlets for their technology transfer activities (ibid. p. 62). This policy had its limitations, and when Stenstadvold stepped back in 1976 he clearly expressed that the dependency on individuals' goodwill and on the university’s organisational structure as well as the lack of strategic power had become a competitive weakness for SINTEF. NTH professors sometimes expressed displeasure with the way SINTEF dominated the contract research market. In 1980 the research institute was reorganised into a private, independent foundation. Similar processes were seen in most other university cities.

Reorganising away from the universities was a mixed blessing, as the industry motives for collaborating with institutes often were related to the recruitment of university graduates (ibid. p. 194). Some firms started dealing more directly with the universities, who on the other hand were often not very experienced with this form of direct interaction. A few years into the new millennium the pattern seems to be reversing. Universities are increasingly taking control of the research institutes in their vicinity. The University of Stavanger has merged its R\&D activities with the institute Rogaland research (RF), and a new phase of NTNU/SINTEF collaboration is seen through the creation of a parallel system for commercialisation of research results. The University of Bergen has gained control of the technological institute Christian Michelsen Research, and the University of Tromsø of the Norut institute group. This is not necessarily the same development as elsewhere in Europe where many research institutes have strengthened their status as independent providers of expertise (cf. Larédo \& Mustar 2001b). But the competition between the sectors for public and private funding continues, and may have increased after all the universities have started technology transfer offices in 2004/2005, carrying out activities that were earlier the domain of the institutes. 


\section{Conclusions}

Norway has followed the same trends and institution-building processes as most other OECD countries. There is nothing extremely unique about the origins and structure of the Norwegian public research system and its relation to industry, although it must be emphasised that some institutions came very late in Norway - in particular stable research funding agencies and industrial laboratories. And Norway is a small country, not able to enter all scientific fields with force as larger countries have done. The need for priorities has always been high on the policy agenda, and even the largest projects have been fairly small in an international comparison. We have looked at a large theme - relations between public sector research (PSR) and industrial development and innovation - and painted a broad picture. Some nuances are lost, and many important innovation policies not related to PSR are left out.

Historically, research policy has been low on the priority list in Norway compared to many other European countries. An economy depending upon natural resources has always taken the attention of policy makers and industrialists away from industries more dependent upon R\&D and innovation. Research has been seen as a vehicle for something else - industrial growth, regional development, increasing quality and efficiency in schools, housing and the public sector etc. - rather than something that should be supported in its own right. This approach is perhaps similar to what can be seen in countries like the U.S., but the size and early wealth of the U.S. still means that the implications are different. A general positive view on science meant that Norway was early in utilising science for practical purposes like mapping of natural resources and experiments related to fish and agriculture. But the build-up of fundamental research in the natural sciences and technology was very slow, although individual professors sometimes succeeded in combining groundbreaking basic research with practical projects of great significance to the economic and social development in Norway. 
The establishment of technical university NTH in 1910 marked the start of a public research effort directed at industrial ends. The first post-WW2 decade in particular was an active period with a host of new organisations including research council NTNF where industry had a clear voice. After WW2 the universities received increased basic funding for the first time and new research institutes came to fill the role the university professors had played before 1945. Over the years a heterogeneous infrastructure of research organisations with a clear mission to contribute to sector-specific knowledge production has emerged. Although inspirations for these organisations have come from institutes in Sweden, the U.S., the U.K. and elsewhere, the system as a whole is perhaps most similar to the German system with its mixture of comprehensive universities, technical universities and specialised colleges, and many different types of research institutes. Wicken (2007) has argued that the Norwegian innovation system has developed different layers - the first termed “decentralised small scale industry", the second "centralised large scale industry" and the third layer "R\&D intensive network based industry”. Different types of public research organisations have been established to cater for the needs of the different layers, e.g. the college of agriculture and industry-specific institutes for Layer 1, university departments as partners of the industrial labs in Layer 2, and commercialisation-oriented institutes for Layer 3. Increasingly, however, we see that the research institutes, and probably also some of the higher education institutions, constitute meeting places for all the layers. This is partly due to the long-time dominance of NTH/SINTEF in technological R\&D and training and partly due to the emergence of the oil industry which strengthened national networks and created strong incentives for many "Layer 3"-oriented research groups to focus their attention on the needs of the firms in "Layer 2". 
The post-war research institutes offered advanced technological solutions to firms where the R\&D intensity was very low. A string of failures, changed funding structure and changed industrial ownership contributed to making the institutes more oriented at incremental changes. The gap between user needs and scientific dreams closed gradually, mainly by the institutes adapting to the existing industrial structure yet convincing the companies to use sophisticated technologies. This process, along with the general collaborative nature of Norwegian companies, has contributed to reinforcing the structure and the incremental innovation approach of Norwegian industry. As many of the traditional industrial companies are alive and highly profitable, this may be seen as a success. The worry of policy-makers remains that there is too little development of new high-tech industries. It could, however, be argued that the dominating industries in Norway are not "low tech" at all, as fish farming, oil/gas extraction and transportation, metals production etc. uses highly sophisticated methods and technologies. Many of these are developed in partnership with public sector research or with companies that owe their existence to such research.

Of course, the main role of public sector research (PSR) in innovation has probably still been to provide firms with a steady flow of human resources. We might perhaps talk about a “public reservoir of competences” (Larédo \& Mustar 2001a:504) where universities and institutes together offer general knowledge, specific solutions, interpretations of problems and mobility of students and experienced researchers. But it can be emphasised that PSR has played an active role in creating new technologies, commercial activities and firms as well. This is obvious through the whole $20^{\text {th }}$ century. 


\section{References}

Andersen, Håkon With, 1997, "Producing Producers: shipping, shipyards and the cooperative infrastructure of the Norwegian maritime complex since 1850" in Sabel, C. and Zeitlin, J. (eds): World of possibilities. Flexibility and mass production in western industrialization. Cambridge: Cambridge University Press, 1997 p. 461-500.

Andersen, Kjetil Gjølme and Gunnar Yttri, 1997, Et forsøk verdt. Forskning og utvikling i Norsk Hydro gjennom 90 år, Scandinavian University Press, Oslo.

Aslesen, Heidi Wiig, 2007, The innovation system of Norwegian aquacultured salmonids. TIK Working Papers on Innovation Studies, Centre for Technology, Innovation and Culture, Oslo.

Basberg, Bjørn L., 1986, “R\&D Performance in Norwegian Electronics Companies, 19601975”, Notat nr. 22 serien Norsk elektronikkhistorie 1945-1970, Teknologihistorieprosjektet, NAVF-NTNF.

Bush, Vannevar, 1945, Science - The Endless Frontier. A report to the President on a program for postwar scientific research, National Science Foundation, Washington D.C.

Collett, John Peter, 1983, Videnskap og politikk. Samarbeide og konflikt om forskning for industriformål 1917-1930. Oslo: Universitetet i Oslo, Hovedoppgave i historie.

Collett, John Peter, 1984, “Elektronikkindustri - nøkkelbransje under særlig omsorg, Arbeidsnotat, Historisk institutt, Universitetet i Oslo,.

Collett, John Peter, 1999, Historien om Universitetet i Oslo, Scandinavian University Press, Oslo.

Collett, Johan Peter og Bjørn Ole Helsing Lossius, 1993, Visjon - Forskning - Virkelighet. TF 25 år, Televerkets Forskningsinstitutt, Kjeller.

Engen, Ole Andreas, 2007, The development of the Norwegian Petroleum Innovation System: A historical overview. TIK Working Papers on Innovation Studies, Centre for Technology, Innovation and Culture, Oslo.

Etzkowitz, Henry and Loet Leydesdorff, 2000, The dynamics of innovation: from national systems and 'Mode 2' to a Triple Helix of university-industry-government relations, Research Policy, 29, 109-123.

Friedman, Robert Marc, 1989, Appropriating the weather: Vilhelm Bjerknes and the construction of a modern meteorology. Ithaca: Cornell University Press.

Gulbrandsen, Magnus and Lars Nerdrum, 2007, University-industry relations in Norway. TIK Working Papers on Innovation Studies, Centre for Technology, Innovation and Culture, Oslo.

Gullowsen, Jon, 2000, Bro mellom vitenskap og teknologi. SINTEF 1950-2000, Tapir Forlag, Trondheim.

Hanisch, Tore J. and Even Lange, 1985, Vitenskap for industrien. NTH - En høyskole i utvikling gjennom 75 år. Scandinavian University Press, Oslo.

Kvaal, Stig, 1997, Janus med tre ansikter. Om organiseringen av den industrielt rettede forskningen i spennet mellom stat, vitenskap og industri i Norge, 1916-1956, Doctoral dissertation, Trondheim.

Larédo, Philippe and Philippe Mustar (eds.), 2001a, Research and innovation policies in the new global economy. Cheltenham: Edward Elgar.

Larédo, Philippe and Philippe Mustar, 2001b, “General conclusion: three major trends in research and innovation policies. In Larédo and Mustar, Research and innovation policies in the new global economy, pp. 497-509.

Martin, Ben R., 2003, "The changing social contract for science and the evolution of the university”, in A. Geuna, A.J. Salter \& W.E. Steinmueller (Editors), Science and 
Innovation. Rethinking the Rationales for Funding and Governance (Edward Elgar, Cheltenham).

Martin, Ben R. and Henry Etzkowitz, 2000, “The origin and evolution of the university species”, VEST Journal for Science and Technology Studies, 13, 9-34.

Moe, Johannes, 1999, På tidens skanser, Tapir Forlag, Trondheim.

Mowery, David C. and Nathan Rosenberg, 1993, “The U.S. National Innovation System.” In Nelson, Richard R. (ed.), National Innovation Systems. A Comparative Analysis. New York/Oxford: Oxford University Press, pp. 29-75.

Nerdrum, Lars and Magnus Gulbrandsen, 2007, The technical-industrial research institutes in the Norwegian innovation system. TIK Working Papers on Innovation Studies, Centre for Technology, Innovation and Culture, Oslo.

Nelson, Richard R., 1993, “A retrospective.” In Nelson (ed.), National Innovation Systems. A Comparative Analysis. New York/Oxford: Oxford University Press, pp. 505-523.

Njølstad, Olav, 1999, Strålende forskning. Institutt for energiteknikk 1948-98, Tano Aschehoug, Oslo.

Njølstad, Olav og Olav Wicken, 1997, Kunnskap som våpen. Forsvarets forskningsinstitutt 1946-1975, Tano Aschehoug, Oslo

Sejersted, Francis, 1993, Demokratisk kapitalisme, Scandinavian University Press, Oslo.

Sogner, Knut, 1997, God på bunnen. SIMRAD-virksomheten 1947-1997, Novus forlag, Oslo.

Sogner, Knut, 2004, Skaperkraft. Elkem gjennom 100 år 1904-2004, Messel Forlag, Oslo

Sogner, Knut, 2007, Slow growth and revolutionary change. The Norwegian IT-industry enters the global age, 1970-2005. TIK Working Papers on Innovation Studies, Centre for Technology, Innovation, and Culture, Oslo.

Skoie, Hans, 2005, Norsk forskningspolitikk i etterkrigstiden. Oslo: Cappelen.

Sörlin, Sverker, 2006, En ny institutssektor - en analys av industriforskningsinstitutens villkor och framtid ur ett närings- och innovationspolitiskt perspektiv. Stockholm: Ireco.

Whitley, Richard, 2003, "Competition and pluralism in the public sciences: the impact of institutional frameworks on the organisation of academic science”, Research Policy, 32:1015-1029.

Wicken, Olav, 1983, “Vekst og våpen. Norsk militærproduksjon som industripolitisk virkemiddel i 1960-årene”, FHFS notat nr. 8/1983, Forsvarets høgskole, Forsvarshistorisk forskningssenter

Wicken, Olav, 1989, ”Norsk datahistorie”, Teknisk ukeblad, Ingeniørforlaget, Oslo.

Wicken, Olav, 1992a, “Samspillet mellom militær og sivil forskning I Norge 1945-1975”, Notat 2/92, NTNF-programmet "Fremtidsrettet teknologipolitikk".

Wicken, Olav, 1992b, "Kald krig i norsk forskning”, Institutt for forsvarstudier, IFS Info nr. 6, 23 sider.

Wicken, Olav, 1994a, ”Elektronikkrevolusjonen” in Olav Wicken red., 1994, Elektronikkentreprenørene. Studier av norsk elektronikkforskning og-industri etter 1945, Ad Notam Gyldendal, Oslo, pp. 10-23.

Wicken, Olav, 1994b, "Teknologi, stat og innovasjoner” in Olav Wicken red., 1994, Elektronikkentreprenørene. Studier av norsk elektronikkforskning og-industri etter 1945, Ad Notam Gyldendal, Oslo, pp. 246-272.

Wicken, Olav, 2007, The Layers of National Innovation Systems: The Historical Evolution of a National Innovation System in Norway. TIK Working Papers on Innovation Studies, Centre for Technology, Innovation and Culture, Oslo.

Ørstavik, Finn, 1994, ”Forskningsingeniører i blandingsøkonomien. FFI som kraftsentrum i norsk teknisk forskning”, in Olav Wicken red., 1984, Elektronikkentreprenørene. Studier av norsk elektronikkforskning og-industri etter 1945, Ad Notam Gyldendal, Oslo, pp. 28-46. 
Ørstavik, Finn, 1996, The hierarchical systems paradigm in technological innovation. A sociological analysis of technology creation and technology policy in the field of minicomputers in Norway. Oslo: University of Oslo, Dr. Philos. thesis. 
Appendix: Central public R\&D organisations in Norway referred to in the paper

\begin{tabular}{|c|c|c|c|}
\hline Acronym & Name (English translation) & Started & Comments \\
\hline CMI & $\begin{array}{l}\text { The Christian Michelsen } \\
\text { Research Institute }\end{array}$ & 1930 & $\begin{array}{l}\text { Located in Bergen. Science and technology activities } \\
\text { were later separated as Christian Michelsen Research } \\
\text { (CMR) in } 1992 \text { (owned jointly by CMI and UiB). }\end{array}$ \\
\hline FFI & $\begin{array}{l}\text { The Norwegian Defence } \\
\text { Research Establishment }\end{array}$ & 1946 & $\begin{array}{l}\text { Located at Kjeller close to Oslo. Departments in other } \\
\text { cities like Bergen and Horten at various points in time. }\end{array}$ \\
\hline IFA/IFE & $\begin{array}{l}\text { The Institute for (Nuclear) } \\
\text { Energy Research }\end{array}$ & 1951 & $\begin{array}{l}\text { This was a spin-out from FFI. After it was decided not to } \\
\text { build commercial nuclear plants in the 1970s, the name } \\
\text { changed to Institute for Energy Research (IFE). It } \\
\text { maintains two nuclear reactors at Kjeller close to Oslo } \\
\text { and in Halden. }\end{array}$ \\
\hline $\mathrm{KV}^{1}$ & Kongsberg Weapons Factory & 1814 & $\begin{array}{l}\text { Perhaps the most important "National Champion" of the } \\
\text { industrial policy of the first three post-WW2 decades. It } \\
\text { was dissolved in } 1987 \text { but the military activities were } \\
\text { continued and now form the "Kongsberg Group" with } \\
4,200 \text { employees. Other civilian activities are found e.g. } \\
\text { in Kongsberg Automotive ( } 2,100 \text { employees). These } \\
\text { firms are private and listed on the Oslo stock exchange. }\end{array}$ \\
\hline NR & $\begin{array}{l}\text { The Norwegian Computing } \\
\text { Centre }\end{array}$ & 1952 & $\begin{array}{l}\text { Located in Oslo. Famous for its role in the development } \\
\text { of the Simula object-oriented computer language. }\end{array}$ \\
\hline $\mathrm{NLH}$ & $\begin{array}{l}\text { The Norwegian College of } \\
\text { Agriculture }\end{array}$ & 1897 & $\begin{array}{l}\text { Located at Ås close to Oslo. University status from } \\
\text { 2005, changed name to University of the Life Sciences. }\end{array}$ \\
\hline NTH & $\begin{array}{l}\text { The Norwegian Institute of } \\
\text { Technology }\end{array}$ & 1910 & $\begin{array}{l}\text { This technological university was merged with the rest } \\
\text { of the University in Trondheim, forming NTNU in } 1996 \text {. }\end{array}$ \\
\hline $\mathrm{NTNF}^{2}$ & $\begin{array}{l}\text { The Norwegian Research } \\
\text { Council for technology and } \\
\text { natural science }\end{array}$ & 1946 & $\begin{array}{l}\text { Together with four other research councils, NTNF was } \\
\text { merged into the Research Council of Norway in } 1993 .\end{array}$ \\
\hline NTNU & $\begin{array}{l}\text { The Norwegian University of } \\
\text { Science and Technology }\end{array}$ & 1996 & $\begin{array}{l}\text { The full merger between NTH and the other parts of the } \\
\text { University in Trondheim. }\end{array}$ \\
\hline $\mathrm{RCN}^{2}$ & $\begin{array}{l}\text { The Research Council of } \\
\text { Norway }\end{array}$ & 1993 & The result of a merger of the five research councils. \\
\hline RF & Rogaland Research & 1973 & $\begin{array}{l}\text { Located in Stavanger close to the college which became } \\
\text { the University of Stavanger in } 2005 \text {. The city is a major } \\
\text { location for oil and gas industry and R\&D. }\end{array}$ \\
\hline SI & $\begin{array}{l}\text { The Central Institute for } \\
\text { Industrial Research }\end{array}$ & 1950 & $\begin{array}{l}\text { Located in Oslo next to the university, merged with } \\
\text { SINTEF in } 1993 \text { under the latter name. }\end{array}$ \\
\hline SINTEF & $\begin{array}{l}\text { The Foundation for industrial } \\
\text { and technological research at } \\
\text { NTH }\end{array}$ & 1950 & $\begin{array}{l}\text { Located in Trondheim next to NTH, several departments } \\
\text { in Oslo. Many different parts, e.g. marine technology } \\
\text { MARINTEK and the electronics lab Elab. }\end{array}$ \\
\hline TF & $\begin{array}{l}\text { The Telephone Agency's } \\
\text { Research Institute }\end{array}$ & 1967 & $\begin{array}{l}\text { Located in Oslo, earlier at Kjeller close to Oslo. } \\
\text { Established as a public research institute but later the } \\
\text { R\&D unit of privatised telephone company Telenor. }\end{array}$ \\
\hline $\mathrm{UiB}$ & The University of Bergen & 1946 & \\
\hline $\mathrm{UiO}$ & The University of Oslo & 1813 & \\
\hline
\end{tabular}

${ }^{1} \mathrm{KV}$ is not strictly a public research organisation (PRO) but was state-owned for a long time and constituted an important partner for many of the PROs.

${ }^{2}$ NTNF and RCN are not strictly PROs either as we use the term in this paper, but they are important public organisations for support of industry-oriented R\&D. 